\title{
Folliculitis to tubercular panniculitis: a clinical diagnostic dilemma!
}

\author{
Parepalli Vinay Kumar, ${ }^{1}$ Chiranth Gowda, ${ }^{1}$ Kanthilatha Pai, ${ }^{2}$ Gabriel Rodrigues (1) ${ }^{3}$
}

${ }^{1}$ General Surgery, Kasturba Medical College Manipal, Manipal, Karnataka, India ${ }^{2}$ Pathology, Kasturba Medical College, Manipal, Karnataka, India

${ }^{3}$ General Surgery, Manipal University Kasturba Medical College, Manipal, India

\section{Correspondence to} Professor Gabriel Rodrigues; gabyrodricks@gmail.com

Accepted 3 August 2021
Check for updates

(C) BMJ Publishing Group Limited 2021. No commercial re-use. See rights and permissions. Published by BMJ.

To cite: Kumar PV, Gowda C, Pai K, et al. BMJ Case Rep 2021;14:e244383. doi:10.1136/bcr-2021244383

\section{DESCRIPTION}

A 68-year-old diabetic man reported with multiple tender swellings over the extremities of 3 days duration and no constitutional symptoms. He had similar episodes in the past, was diagnosed to have folliculitis with abscess formation and undergone incision and drainage (I\&D) multiple times. Pus culture had failed to grow an organism every time. Examination revealed multiple, tender, firm subcutaneous nodules with surrounding cutaneous erythema on the medial aspect of the left lower thigh and right forearm (figure 1A,B). Respective draining lymph nodes were not enlarged. As there was no fluctuation, an abscess was ruled out and a biopsy of the forearm nodule was done. GeneXpert was mildly positive for tuberculosis (TB) and histopathological examination revealed well-circumscribed epithelioid granulomas, Langhans giant cells (arrow) and a dense lymphocytic infiltrate, consistent with tuberculous (granulomatous) panniculitis (figure 2). He was further evaluated and had a strong positive Mantoux test. Blood investigations and CXR were normal. A connective tissue disease workup and HIV were negative. He was started on antituberculous chemotherapy (isoniazid, rifampicin, pyrazinamide and ethambutol for 2 months followed by isoniazid and rifampicin for 4 months) and made a good recovery with resolution of all the nodules. On follow-up at regular intervals for the past 2 years, he is in good health and there has been no recurrence of the disease.

TB, the 'King's evil', known since 2000 BC, a chronic disease caused by an acid-fast bacillus (AFB), aerobic bacillus Mycobacterium tuberculosis (MTB), has been a major cause of morbidity in developing nations. Currently around 2 billion people across the world have been infected with 10.4 million new detection every year and approximately one-third of the people worldwide are carriers of the bacillus. ${ }^{1}$

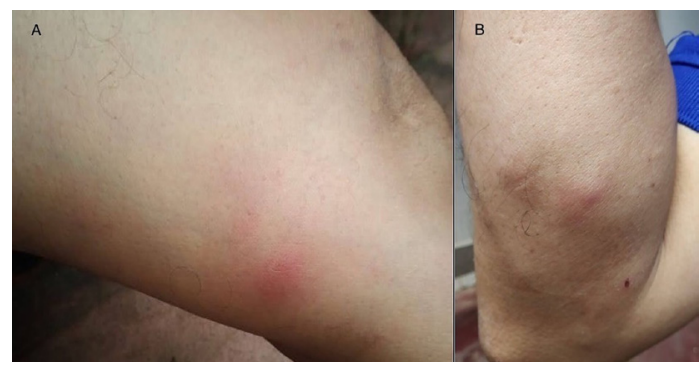

Figure 1 Subcutaneous nodules with cutaneous inflammation of extremities (A, B).

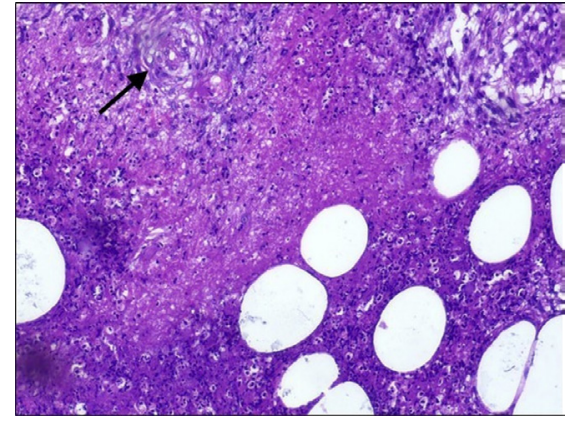

Figure 2 Photomicrograph showing granulomatous panniculitis with well-circumscribed epithelioid granulomas, Langhans giant cells (arrow) and dense lymphocytic infiltrate. $\times 200, \mathrm{H} \& \mathrm{E}$.

Panniculitis is an inflammation of the subcutaneous adipose tissue and $\mathrm{TB}$ affecting skin and subcutaneous fat is extremely rare (1\%-1.5\% of extrapulmonary TB) and mimic sarcoidosis, systemic lupus erythematosus, tuberculoid leprosy and mycetoma, to name a few. Though painless recurrent nodules or plaques commonly seen on the legs that may ulcerate leaving a pigmented scar is the usual presentation, ${ }^{2}$ our patient had painful nodules on both extremities with overlying skin erythema that was probably misdiagnosed as folliculitis with abscess, for which he had undergone I\&D many times. Classical symptoms of TB are rarely seen and hence cause diagnostic dilemma in arriving at a definitive clinical diagnosis.

A variety of nodular subcutaneous lesions have been described occurring in patients with TB like erythema induratum (nodular vasculitis), erythema nodosum and erythema induratum of Bazin (EIB). When present, they might herald a sign of systemic disease. EIB is a chronic, nodular eruption affecting the lower extremities in young women that has

\section{Learning points}

- Tuberculosis (TB) panniculitis is a rare entity that can be confused with folliculitis and nodular connective tissue disorders.

- Excision and histopathological examination of the nodule is a must for a definitive diagnosis and antituberculous treatment (ATT) is curative.

- A differential diagnosis of TB panniculitis should be considered in patients with recurrent skin and subcutaneous nodules especially in tropical countries. 
been regarded as a manifestation of tuberculin hypersensitivity, a type of tuberculid occurring on the legs. ${ }^{34}$

For a definitive diagnosis, an excision and histopathological examination of the nodule is mandatory where granulomatous inflammation with necrosis, epithelioid cells, giant cells and lymphocytes confirm the diagnosis of TB panniculitis. Further an erythrocyte sedimentation rate (ESR), chest $\mathrm{x}$-ray (CXR), sputum for AFB, Mantoux skin test should be done to identify the focus of infection. Antituberculous drugs usually given for 6 months are curative. A close follow-up for recurrence of skin and subcutaneous nodules is mandatory and if present indicate resistant strains of MTB that require determination of drug resistance and sequencing.

Contributors GR, PVK: conceptualisation, drafting. GR, PVK, KP and CG: editing, final approval.
Funding The authors have not declared a specific grant for this research from any funding agency in the public, commercial or not-for-profit sectors.

Competing interests None declared.

Patient consent for publication Obtained.

Provenance and peer review Not commissioned; externally peer reviewed.

ORCID iD

Gabriel Rodrigues http://orcid.org/0000-0002-0488-5040

\section{REFERENCES}

1 Barberis I, Bragazzi NL, Galluzzo L, et al. The history of tuberculosis: from the first historical records to the isolation of Koch's Bacillus. J Prev Med Hyg 2017;58:E9-12.

2 Rabinowitz LO, Zaim MT. A clinicopathologic approach to granulomatous dermatoses. J Am Acad Dermatol 1996;35:588-600.

3 Gilchrist H, Patterson JW. Erythema nodosum and erythema induratum (nodular vasculitis): diagnosis and management. Dermatol Ther 2010;23:320-7.

4 Mascaró JM, Baselga E. Erythema induratum of Bazin. Dermatol Clin 2008;26:439-45.

Copyright 2021 BMJ Publishing Group. All rights reserved. For permission to reuse any of this content visit

https://www.bmj.com/company/products-services/rights-and-licensing/permissions/

BMJ Case Report Fellows may re-use this article for personal use and teaching without any further permission.

Become a Fellow of BMJ Case Reports today and you can:

- Submit as many cases as you like

- Enjoy fast sympathetic peer review and rapid publication of accepted articles

- Access all the published articles

Re-use any of the published material for personal use and teaching without further permission

Customer Service

If you have any further queries about your subscription, please contact our customer services team on +44 (0) 2071111105 or via email at support@bmj.com.

Visit casereports.bmj.com for more articles like this and to become a Fellow 